Provided for non-commercial research and education use. Not for reproduction, distribution or commercial use.

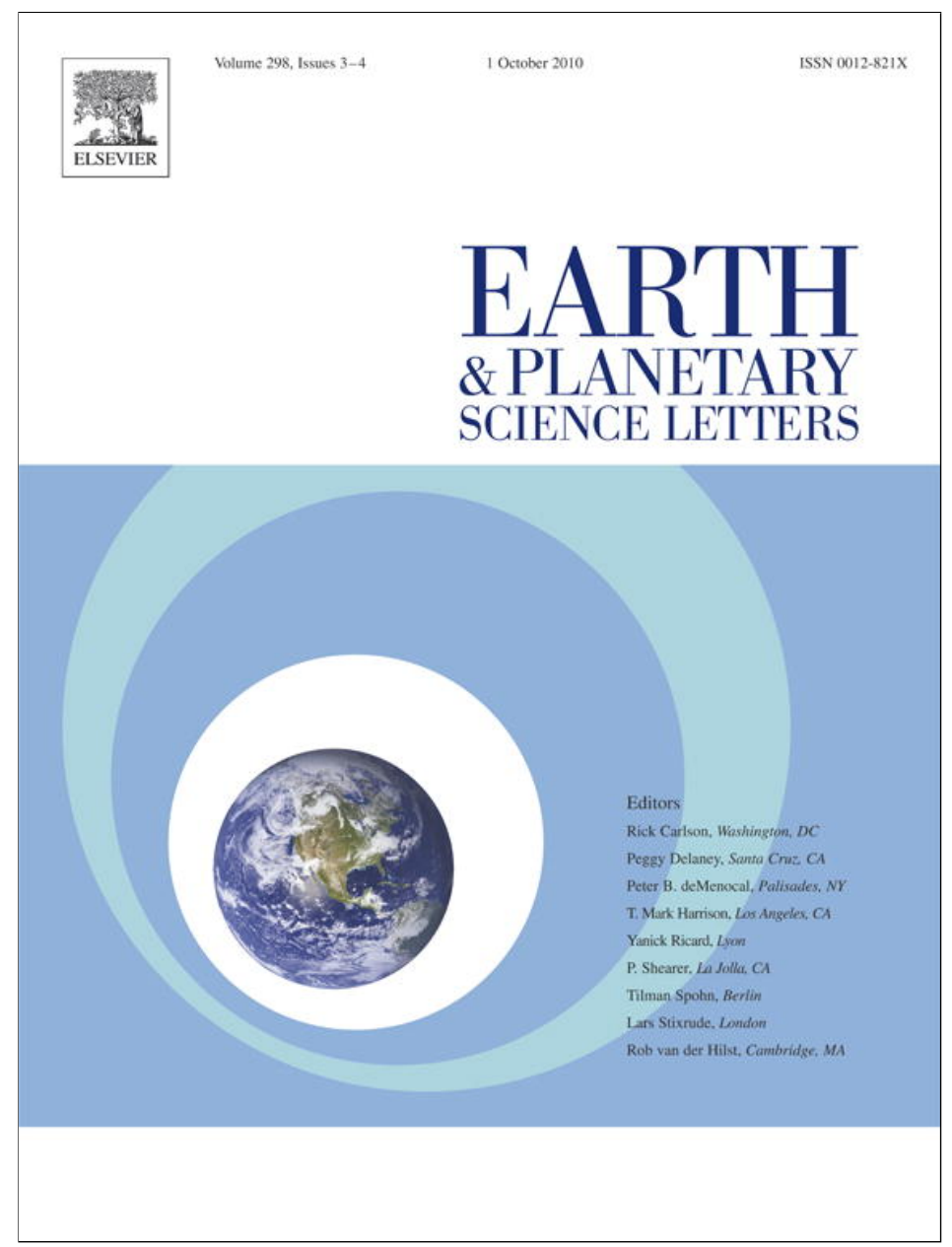

This article appeared in a journal published by Elsevier. The attached copy is furnished to the author for internal non-commercial research and education use, including for instruction at the authors institution and sharing with colleagues.

Other uses, including reproduction and distribution, or selling or licensing copies, or posting to personal, institutional or third party websites are prohibited.

In most cases authors are permitted to post their version of the article (e.g. in Word or Tex form) to their personal website or institutional repository. Authors requiring further information regarding Elsevier's archiving and manuscript policies are encouraged to visit:

http://www.elsevier.com/copyright 


\title{
Late Pliocene changes in the North Atlantic Current
}

\author{
B. David A. Naafs ${ }^{\mathrm{a}, \mathrm{b}, *}$, Ruediger Stein ${ }^{\mathrm{a}}$, Jens Hefter $^{\mathrm{a}}$, Nabil Khélifi ${ }^{\mathrm{c}}$, Stijn De Schepper ${ }^{\mathrm{d}}$, Gerald H. Haug ${ }^{\mathrm{b}, \mathrm{e}}$ \\ a Alfred Wegener Institute for Polar and Marine Research, D-27568 Bremerhaven, Germany \\ ${ }^{\mathrm{b}}$ Leibniz Center for Earth Surface and Climate Studies, Institute for Geosciences Potsdam University, D-14476 Potsdam, Germany \\ c Institute for Geosciences, University of Kiel, D-24118, Germany \\ ${ }^{d}$ Department of Geosciences, University of Bremen, D-28334 Bremen, Germany \\ e Geological Institute, ETH Zürich, 8092 Zürich, Switzerland
}

\section{A R T I C L E I N F O}

\section{Article history:}

Received 28 April 2010

Received in revised form 16 August 2010

Accepted 17 August 2010

Available online 15 September 2010

Editor: M.L. Delaney

\section{Keywords:}

North Atlantic Current

Northern Hemisphere glaciation

SST

Pliocene

alkenones

IODP Site U1313

\begin{abstract}
A B S T R A C T
During the late Pliocene global climate changed drastically as the Northern Hemisphere glaciation (NHG) intensified. It remains poorly understood how the North Atlantic Current (NAC) changed in strength and position during this time interval. Such changes may alter the amount of northward heat transport and therefore have a large impact on climate in the circum-North Atlantic region and the growth of Northern Hemisphere ice sheets. Using the alkenone biomarker we reconstructed orbitally resolved sea surface temperature (SST) and productivity records at Integrated Ocean Drilling Project (IODP) Expedition 306 Site U1313 during the late Pliocene and early Pleistocene, 3.68-2.45 million years ago (Ma). Before 3.1 Ma, SSTs in the mid-latitude North Atlantic were up to $6{ }^{\circ} \mathrm{C}$ higher than the present and surface water productivity was low, indicating that an intense NAC transported warm, nutrient-poor surface waters northwards. Starting at 3.1 Ma, surface water characteristics changed drastically as the NHG intensified. During glacial periods at the end of the late Pliocene and beginning of the Pleistocene, SSTs decreased and surface water productivity in the mid-latitude North Atlantic increased, reflecting a weakened influence of the NAC at our site. At the same time the increase in surface productivity suggests that the Arctic Front (AF) reached down into the mid-latitudes. We propose that during the intensification of the NHG the NAC had an almost pure west to east flow direction in glacials and did not penetrate into the higher latitudes. The diminished northward heat transport would have led to a cooling of the higher latitudes, which may have encouraged the growth of large continental ice sheets in the Northern Hemisphere.
\end{abstract}

(c) 2010 Elsevier B.V. All rights reserved.

\section{Introduction}

The Pliocene epoch ${ }^{1}$ is the most recent period in geological history when global temperatures were several degrees higher than today (e.g., Dowsett et al., 2009; Haywood et al., 2009). Atmospheric $\mathrm{pCO}_{2}$ was approximately $100 \mathrm{ppm}$ higher than pre-industrial levels (Pagani et al., 2010) and ice sheets in the Northern Hemisphere were relatively small. The general surface current system was similar to the present one (Dowsett et al., 2009), but sea surface temperatures (SSTs) in the North Atlantic Ocean were up to $10^{\circ} \mathrm{C}$ warmer compared to the present as an intense North Atlantic Current (NAC) led to a reduced meridional SST gradient (e.g., Cronin, 1991; Dowsett et al., 1992; Robinson, 2009).

* Corresponding author. Alfred Wegener Institute for Polar and Marine Research, D-27568 Bremerhaven, Germany. Tel.: +49 471 48312120; fax: +49 47148311923. E-mail address: david.naafs@awi.de (B.D.A. Naafs).

${ }^{1}$ Please note we use the updated definitions of the early Pliocene (5.332-3.6 Ma), late Pliocene (3.6-2.588 Ma), and early Pleistocene (2.588-0.781 Ma) (Gibbard et al., 2009).
During the late Pliocene these warm conditions terminated as the Northern Hemisphere glaciation (NHG) intensified and the Quaternarystyle climate that characterizes the Pleistocene epoch developed. The exact timing of the intensification of NHG is not well constrained and differs between studies and site locations. In benthic foraminiferal $\delta^{18} \mathrm{O}$ records, a measure for high latitude temperature and continental ice volume, the increase started around 3.6 Ma, indicating the built-up of continental ice sheets in the Northern Hemisphere (Mudelsee and Raymo, 2005). However, the threshold towards full glacial/interglacial conditions is located near 2.7 Ma during the Marine Isotope Stage (MIS) G6 when the amplitude of the 41-ka component increased (Ruggieri et al., 2009). Around the same time ice-rafted debris (IRD) became widespread in sediments from the higher latitudes (e.g., Kleiven et al., 2002; Maslin et al., 1998; Shackleton et al., 1984). MIS G6 is therefore considered as the first intense glacial period with large Northern Hemisphere ice sheets.

Various hypotheses such as a change in orbital configuration, a decrease in atmospheric $\mathrm{pCO}_{2}$ via polar ocean stratification, and/or changes in oceanic and atmospheric heat transport, possibly related to the closing of the Central American Seaways (CAS), have been proposed as cause for the intensification of the NHG (Bartoli et al., 2005; Driscoll and Haug, 1998; Haug and Tiedemann, 1998; Haug et al., 
1999, 2005; Haywood et al., 2000; Lawrence et al., 2009; Maslin et al., 1998; Mudelsee and Raymo, 2005; Ravelo et al., 2004; Sarnthein et al., 2009; Seki et al., 2010). So far, none of these have given a complete satisfactory explanation and the ultimate cause remains an enigma. Nevertheless, recent studies suggest that cooling of the higher latitudes and increase in meridional SST gradient were crucial for the intensification of NHG (Berger and Wefer, 1996; Brierley and Fedorov, 2010; De Schepper et al., 2009; Lunt et al., 2008). This means that the NAC, by which the excess in heat from the tropics was transported northwards during the Pliocene, had to weaken and/or change its path during the intensification of the NHG in order to allow the higher latitudes to cool and the meridional SST gradient to increase. This contradicts other hypotheses in which an increase in northward heat transport, related to closure of the CAS, and associated feedback mechanisms are suggested as the main cause for the intensification of the NHG (e.g., Bartoli et al., 2005; Driscoll and Haug, 1998; Haug and Tiedemann, 1998).

Therefore reconstructing the influence of the NAC on the North Atlantic during the late Pliocene is crucial for a better understanding of the mechanisms behind the intensification of the NHG. At present, only one study discussing variations in northward heat transport is available for the complete late Pliocene (Lawrence et al., 2009). However, that study used samples from Ocean Drilling Project (ODP) Site 982. This site is located at the northern end of the NAC and probably does not reflect major variations in the position and strength of the main branch of the NAC. This is obvious in view of the highamplitude SST variability, which is most likely related to short-term variability in the most northern position of the NAC (Lawrence et al., 2009). More important, the age model of Site 982 for the late Pliocene might require revision (Khélifi and Sarnthein, 2010). Therefore, this study is based on sediment samples from the more southerly located Integrated Ocean Drilling Project (IODP) Expedition 306 Site U1313. The main objective of this paper is to reconstruct variations in the NAC and the subsequent change in northward heat transport during the late Pliocene, when the NHG intensified.

\section{Regional setting}

The North Atlantic is characterized by a continuous northward flow of warm and salty surface water that constitutes the upper part of the meridional overturning circulation (Fig. 1). At the origin of the surface current system is the Gulf Stream, which continues as the North Atlantic Current (NAC) and finally the North Atlantic Drift Current in the northeast North Atlantic. We use the term NAC to refer to the whole warm surface current that continues after the Gulf Stream into the northeast North Atlantic. The NAC forms the transition zone between the two different regimes: in the higher latitudes the cold and productive Arctic waters, in the subtropics the warm and oligotrophic waters from the subtropical gyre (Fig. 1). The region of high surface water productivity just north of the NAC is associated with the location of the Artic Front (AF), which is characterized by high eddy activity that promotes surface water productivity.

Various studies showed that surface water characteristics in the (mid-latitude) North Atlantic mainly depend on the strength and position of the NAC, which in turn determines the position of oceanic fronts (e.g., Calvo et al., 2001; Lawrence et al., 2009; Robinson, 2009; Stein et al., 2009; Versteegh et al., 1996; Villanueva et al., 2001). High SSTs indicate an intense NAC transporting warm surface waters northwards across the mid-latitude North Atlantic, whereas cooler SSTs reflect a weakened influence of the NAC.

Alkenone ARs provide a second measure of variability in the NAC. Both coccolith carbonate and alkenone abundance have been used to track the movement of the high productivity zone associated with the AF during the middle and late Pleistocene (e.g., McIntyre et al., 1972; Stein et al., 2009; Villanueva et al., 2001). These studies showed that during glacials the productivity maximum moved southwards as the AF shifted into the mid-latitude North Atlantic, cold polar waters expanded to lower latitudes, and the NAC did not influence the higher latitudes in the northeast Atlantic. A reconstruction of SSTs for the Last Glacial Maximum depicts this almost purely west to east flow

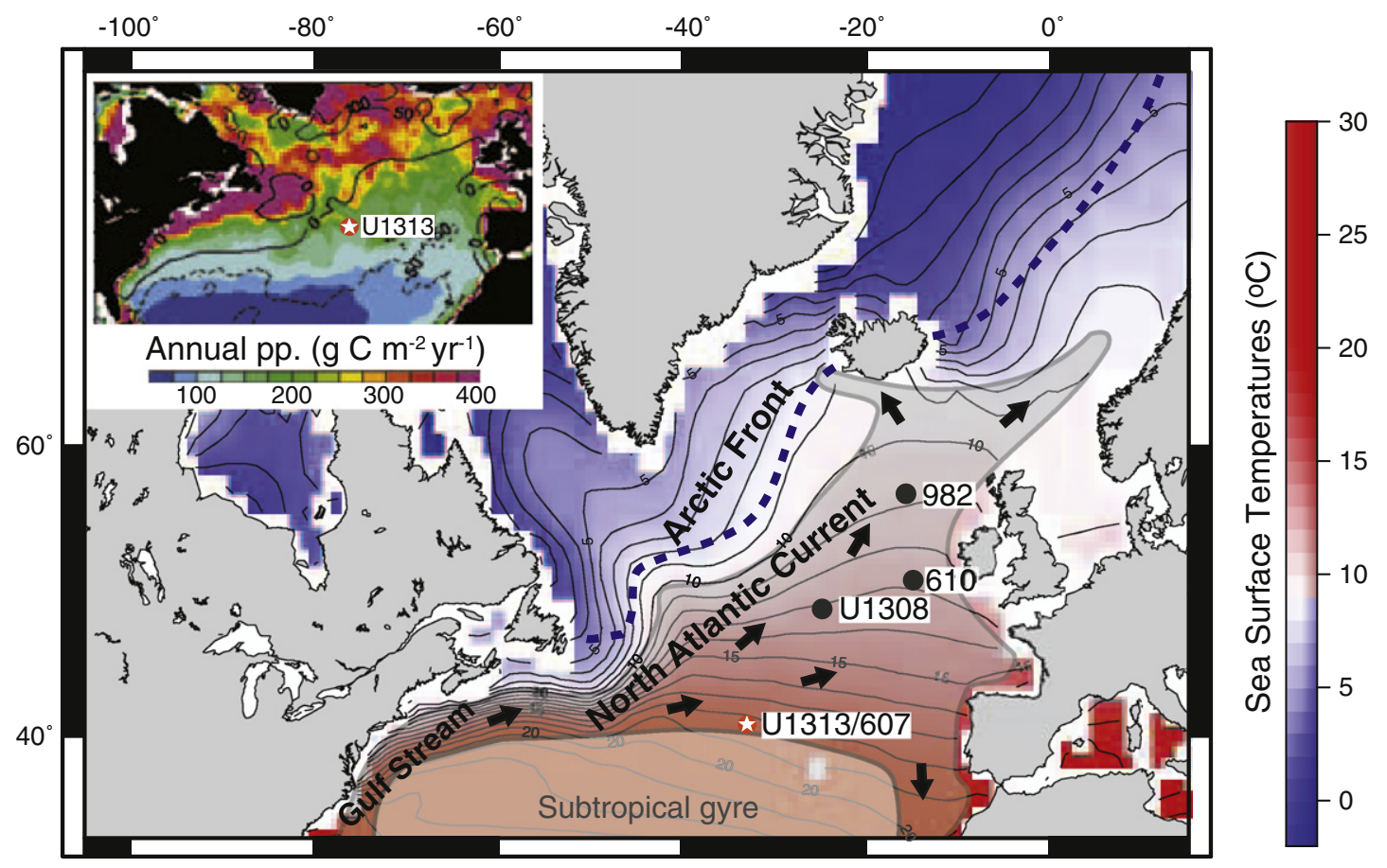

Fig. 1. Map of the North Atlantic Ocean showing modern mean annual SSTs at the surface (Locarnini et al., 2006) together with the position of the Gulf Stream and North Atlantic Current (NAC). Dashed line shows the position of the Arctic Front (AF), which separates warm Atlantic waters in the mid-latitudes from cold subpolar waters in the higher latitudes (Pflaumann et al., 2003; Swift, 1986). Insert shows annual primary productivity (pp.) in the North Atlantic (modified from Williams and Follows, 1998). The NAC forms the transition zone between warm and oligotrophic waters of the subtropical gyre to the south and cold and productive Arctic waters associated with the AF in the north. In this study we used samples from IODP Site U1313, a re-drill of DSDP Site 607, which at present is located under the direct influence of the NAC. Other sites discussed in the text are also shown. 
direction of warm surface waters and southern position of the AF between 37 and $45^{\circ} \mathrm{N}$ (Pflaumann et al., 2003), which led to increased surface water productivity in the mid-latitude North Atlantic (Villanueva et al., 2001).

Since surface water characteristics are so different to the north and the south of the NAC, a change in position of the NAC as described above can lead to large changes in SSTs and productivity at Site U1313, which at present is located under the direct influence of the NAC. Records of surface water characteristics at site U1313 are therefore well suited to reconstruct changes in the position and strength of the NAC.

\section{Material and methods}

\subsection{Age model Site U1313}

Site U1313 is a re-drill of Deep Sea Drilling Project (DSDP) Site 607 and is located at the base of the upper western flank of the Mid-Atlantic Ridge ( $3426 \mathrm{~m}$ water depth, latitude $41^{\circ} 00^{\prime} \mathrm{N}$, longitude $32^{\circ} 57^{\prime} \mathrm{W}$ ). Four holes were drilled at Site U1313 to obtain a continuous sedimentary record (Expedition 306 Scientists, 2006). Using the holes U1313B and U1313C a complete spliced stratigraphic section was obtained. The original meter composite depth (mcd)-scale was updated to an adjusted, so-called amcd-scale, to improve the overall correlation of distinct features in the lightness, susceptibility, and paleomagnetic data between the holes. Slight adjustments were made to the mcd-scale of Hole U1313C, which was tied to the mcd-scale for Hole U1313B (G. Acton, personal communication). We obtained an age model for the period between 3.65 and $2.45 \mathrm{Ma}$ by improving and extending the preliminary shipboard age model for Site U1313 (Expedition 306 Scientists, 2006). The age model is based on tuning the lightness record of the primary splice to the global benthic foraminiferal $\delta^{18} \mathrm{O}$ LR04 stack (Lisiecki and Raymo, 2005), using the Match 2.0 software (Lisiecki and Lisiecki, 2002). We assumed that the variability in lightness, caused by changing carbonate content due to variations in terrestrial input, mimicked changes in benthic foraminiferal $\delta^{18} \mathrm{O}$ without any temporal offset during the late Pliocene and early Pleistocene (Expedition 306 Scientists, 2006). This assumption is supported by data from DSDP Site 607 where changes in carbonate content, hence lightness, are in phase with benthic foraminiferal $\delta^{18} \mathrm{O}$ at the obliquity rhythm (Ruddiman et al., 1989). Depth-age tie-points were based on the magnetostratigraphy of Site U1313 (Expedition 306 Scientists, 2006) and visual correlation between the two records. The resulting sedimentation rates vary between 2 and $10 \mathrm{~cm} / \mathrm{ka}$ (Fig. 2). The ages obtained for magnetic reversals at Site U1313, which can clearly be identified in the inclination record (Fig. 2), all match the ages as given by Lisiecki and Raymo, (2005) within the error margin.

\subsection{Sample preparation and methods}

Samples of $10 \mathrm{cc}$ were taken from the primary splice at a $20 \mathrm{~cm}$ ( $\pm 4 \mathrm{ka}$ ) resolution. Between 2.78 and $2.65 \mathrm{Ma}$ (MIS G9-G3) sampling resolution was $10 \mathrm{~cm}( \pm 2 \mathrm{ka})$. All samples were freeze-dried after sampling and stored at $4{ }^{\circ} \mathrm{C}$ until further processing.

A LECO Pegasus III GC/TOF-MS system was used to measure the biomarker content of the sediment samples. This method has recently been established as alternative for alkenone analyses and has the advantage over classical GC/FID methods that it significantly reduces instrumental time and has a higher sensitivity (Hefter, 2008). Full details of the methods applied are discussed elsewhere (Hefter, 2008; Stein et al., 2009). In short, organic compounds were obtained from around $6 \mathrm{~g}$ of

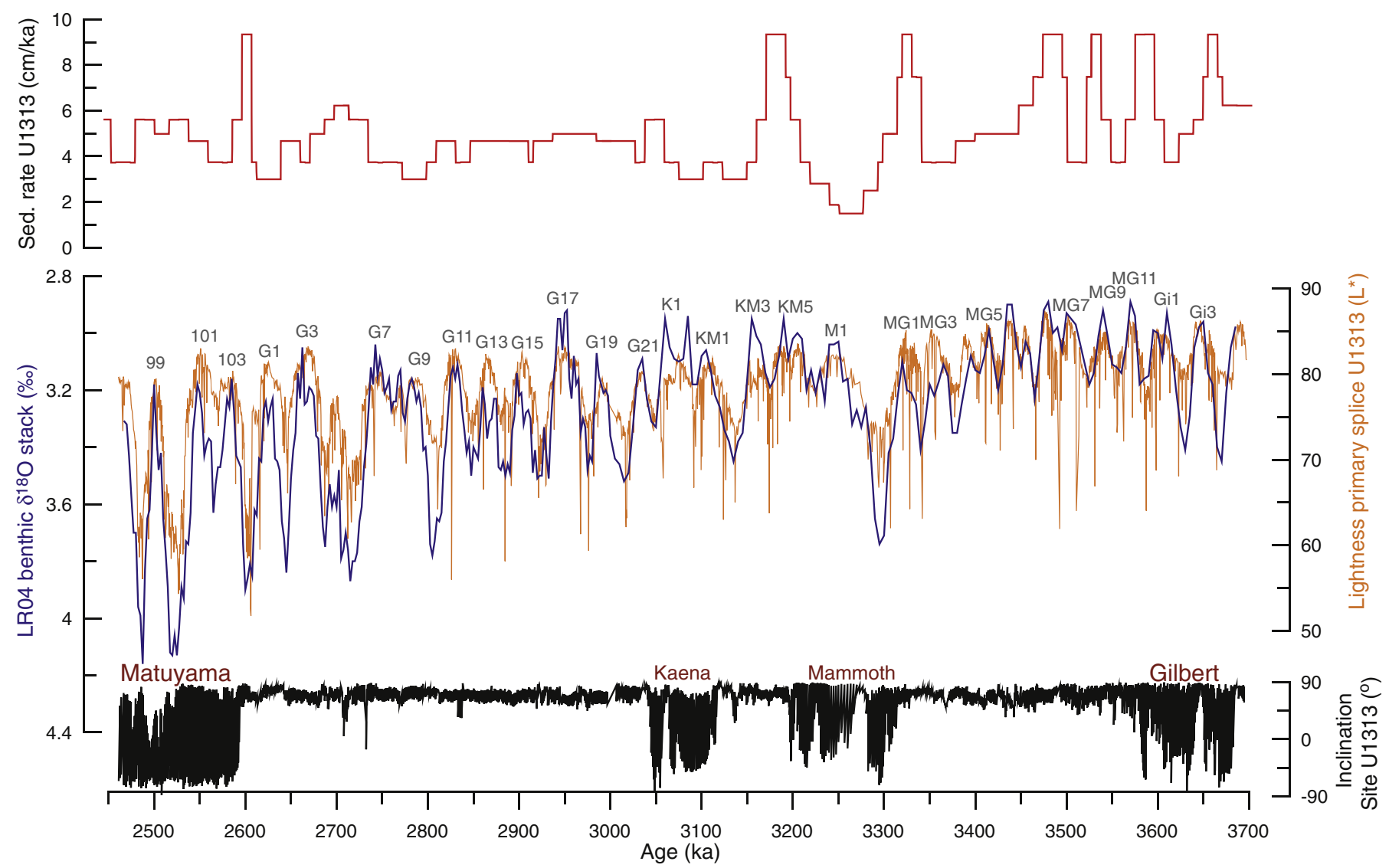

Fig. 2. Age model for Site U1313. The age model is based on tuning of the lightness of the primary splice (orange) to the global benthic foraminiferal $\delta^{18} \mathrm{O}$ stack (blue) (Lisiecki and Raymo, 2005). The resulting sedimentation rates vary between 2 and $10 \mathrm{~cm} / \mathrm{ka}$ (red). Also shown are the inclination data for the primary splice of Site U1313 (black) and matching polarity chrons. 
freeze-dried and homogenized sediment using dichloromethane and accelerated solvent extraction (ASE 200, DIONEX, 5 min. at $100{ }^{\circ} \mathrm{C}$ and $1000 \mathrm{psi}$ ). For quantification purposes, $2.1435 \mu \mathrm{g}$ of n-hexatriacontane ( $n$ - $C_{36}$ alkane) were added to each sample as standard prior to extraction. Total extracts were concentrated, dried under a nitrogen flow and then re-dissolved in $0.5 \mathrm{ml}$ hexane before being measured by the GC/TOF-MS system. The alkenone unsaturation index $\left(U_{37}^{k^{\prime}}\right)$ was used together with the global core-top calibration (Müller et al., 1998; Prahl and Wakeham, 1987) to reconstruct mean annual temperatures at the surface (top 10 meters). Total $C_{37}$ alkenone $\left(C_{37: 2}+C_{37: 3}\right)$ accumulation rates (ARs) in $\mathrm{ng} / \mathrm{cm}^{2} / \mathrm{ka}$ were calculated using linear sedimentation rates (Fig. 2), biomarker concentrations obtained by the GC/TOF-MS system, and dry bulk densities (DBD), calculated from shipboard measured wet bulk densities (WBD) using DBD $=-1.6047+1.5805$ * WBD (Expedition 306 Scientists, 2006; Stein et al., 2009).

\subsection{Reliability of $U_{37}^{k^{\prime}}$ in the late Pliocene}

In the modern ocean alkenones are produced by the members of the class Prymnesiophyceae, primarily Emiliania huxleyi as well as Gephyrocapsa oceanica (e.g., Volkman et al., 1995). Both species first appeared in the mid-latitude North Atlantic during the (middle) Pleistocene (Expedition 306 Scientists, 2006), but alkenones are found in much older sediments. Then, other extant and extinct members of the class Prymnesiophyceae presumably produced the alkenones. Although the alkenone producers changed over time, previous work has shown that $U_{37}^{k^{\prime}}$ and global core-top calibration are applicable beyond the first occurrence of E. huxleyi (McClymont et al., 2005; Villanueva et al., 2002). In recent years the alkenone thermometer was therefore used to produce several long-term SST records (e.g., Dekens et al., 2007; Lawrence et al., 2009), showing the capability to provide reliable temperature estimates for at least the last $5 \mathrm{Ma}$.

In the mid-latitudes seasonal fluctuations in alkenone production most likely cause only a small bias in SST reconstructions towards the temperature of the growing season (Conte et al., 2006; Müller et al., 1998). Therefore our SST record is interpreted to reflect mean annual temperatures. This is supported by an alkenone-derived SST of $18.2^{\circ} \mathrm{C}$ from our core-top sample, within the error identical to the modern mean annual SST of $18.3^{\circ} \mathrm{C}$ at Site U1313 (Locarnini et al., 2006). Even so, recent work has suggested that at least during the interglacials of the late Pleistocene, alkenone-based SSTs in the mid-latitude North Atlantic reflect spring temperatures (Leduc et al., 2010). If this was also the case in the late Pliocene then the increase in Pliocene SSTs compared to the modern is underestimated (compare Pliocene SSTs with modern spring SST instead of annual mean SST in Fig. 3).

The input of allochthonous alkenones likely did not significantly affect our biomarker records from the mid-latitude North Atlantic since this is more important in the higher latitudes such as the Nordic Seas (Bendle et al., 2005) or at sites located on or close to continental margins (e.g., Mollenhauer et al., 2005).

\section{Results}

The SST record from Site U1313 ranges from 3.65 to $2.45 \mathrm{Ma}$ and demonstrates both long- and short-term variability during this period (Fig. 3). SST variability is similar to the global benthic foraminiferal $\delta^{18} \mathrm{O}$ stack (Lisiecki and Raymo, 2005). Intervals of low benthic foraminiferal $\delta^{18} \mathrm{O}$ coincide with periods of increased SSTs at Site U1313 and vice versa. During most of the late Pliocene, SSTs were higher than the present with interglacial temperatures occasionally as high as $24^{\circ} \mathrm{C}$, in accordance with the general consensus of a warm North Atlantic Ocean during the late Pliocene (see Lawrence et al., 2009 and references therein). SSTs decreased between 3.5 and 3.3 Ma by $5{ }^{\circ} \mathrm{C}$, culminating in MIS M2 with values as low as $17^{\circ} \mathrm{C}$. The Pliocene Research Interpretation and Synoptic Mapping (PRISM)-interval between 3.29 and 2.97 Ma (Dowsett et al., 2009), is characterized by high SSTs with both glacial and interglacial values higher than the present. From 3.1 Ma onwards SSTs got progressively lower. Especially glacial SSTs decreased by several degrees at the end of our record with the lowest SSTs found during MIS G6 $\left(15^{\circ} \mathrm{C}\right)$ and $100\left(13^{\circ} \mathrm{C}\right)$.

Alkenone ARs are generally low and show little variation during most of our record with typical values of around $500 \mathrm{ng} / \mathrm{cm}^{2} / \mathrm{ka}$. The exception is during MIS G6, 104, 100, and 98 when intense cooling of surface waters coincides with an increase in alkenone ARs by one order of magnitude, reaching values as high as $8000 \mathrm{ng} / \mathrm{cm}^{2} / \mathrm{ka}$ (Fig. 3).

\section{Discussion}

Variations in the surface water characteristics at Site U1313 are interpreted to reflect changes in the influence of the NAC. The shift from warm and oligotrophic conditions at our site towards cold and more productive surface waters during the latest Pliocene and early Pleistocene (Fig. 3) suggests a process comparable to that of glacials of the late Quaternary when the NAC had an almost purely west to east flow direction and the AF was located close to our study site. Below we discuss the changes in surface water characteristics at Site U1313 and, hence, the influence of the NAC for different time intervals of the late Pliocene and early Pleistocene.

\subsection{Period between 3.68 and $3.45 \mathrm{Ma}$ : warm beginning of the late Pliocene}

High SSTs and low alkenone ARs during this period suggest that throughout this interval an intense NAC transported warm waters northwards, keeping the higher latitudes warm. SSTs at Site 982 in the northern North Atlantic also record warm surface waters during this interval (Lawrence et al., 2009), suggesting that the entire North Atlantic was influenced by an intense NAC. At that time, Site U1313 was likely bathed with waters from the subtropical gyre since this gyre likely expanded in the warm Pliocene. The NAC then may have followed a more northern pathway compared to present, keeping the high productivity region associated with the AF far to the north of our study site.

A short alkenone-based SST record from DSDP Site 607 (Lawrence et al., 2009), of which U1313 is a re-drill, is in good agreement with our record. The only difference is the low SSTs at Site U1313 during MIS MG12 ( \pm 3.59 Ma). At Site 607 lowest SSTs occur during MIS Gi2 $( \pm 3.63 \mathrm{Ma})$. Lowest SSTs during MIS Gi2 seem to better fit benthic foraminiferal $\delta^{18} \mathrm{O}$, with heavier values during MIS Gi2 (Lisiecki and Raymo, 2005). However at Site U1313 the excellent resolved inclination data (Fig. 2) shows that the Guass/Gilbert magnetic boundary coincides with these low SSTs. The Gauss/Gilbert boundary in the LR04 stack has an age of $3.588 \mathrm{Ma}$ and is placed within MIS MG12 (Lisiecki and Raymo, 2005). We are therefore certain that the low SSTs at Site U1313 occur during MIS MG12. At Site 607 identification of magnetic polarity chrons is problematic in this interval, preventing us to be certain that the SST records are truly different. Possibly future benthic oxygen isotope stratigraphy at Site U1313 can help to resolve this.

\subsection{Period between 3.45 and 3.29 Ma: towards MIS M2}

Decreasing SSTs during this period suggest the influence of the NAC, and hence northward heat transport, weakened prior to MIS M2. Low alkenone ARs suggest that despite the weakening of the NAC, it was still strong enough to prevent nutrient rich waters and the AF to reach the core site. This is supported by data of IRD, which is recorded only at sites north of $50{ }^{\circ} \mathrm{N}$ (Kleiven et al., 2002). The absence of IRD in more southern sites suggests that warm surface waters were still influencing the mid-latitude North Atlantic and prevented icebergs from reaching further south.

Although covering only a small time interval around MIS M2, Mg/Ca based SST and dinoflagellate cyst assemblages from the northern North Atlantic (DSDP Site 610 and IODP Site U1308) also show a reduction in 


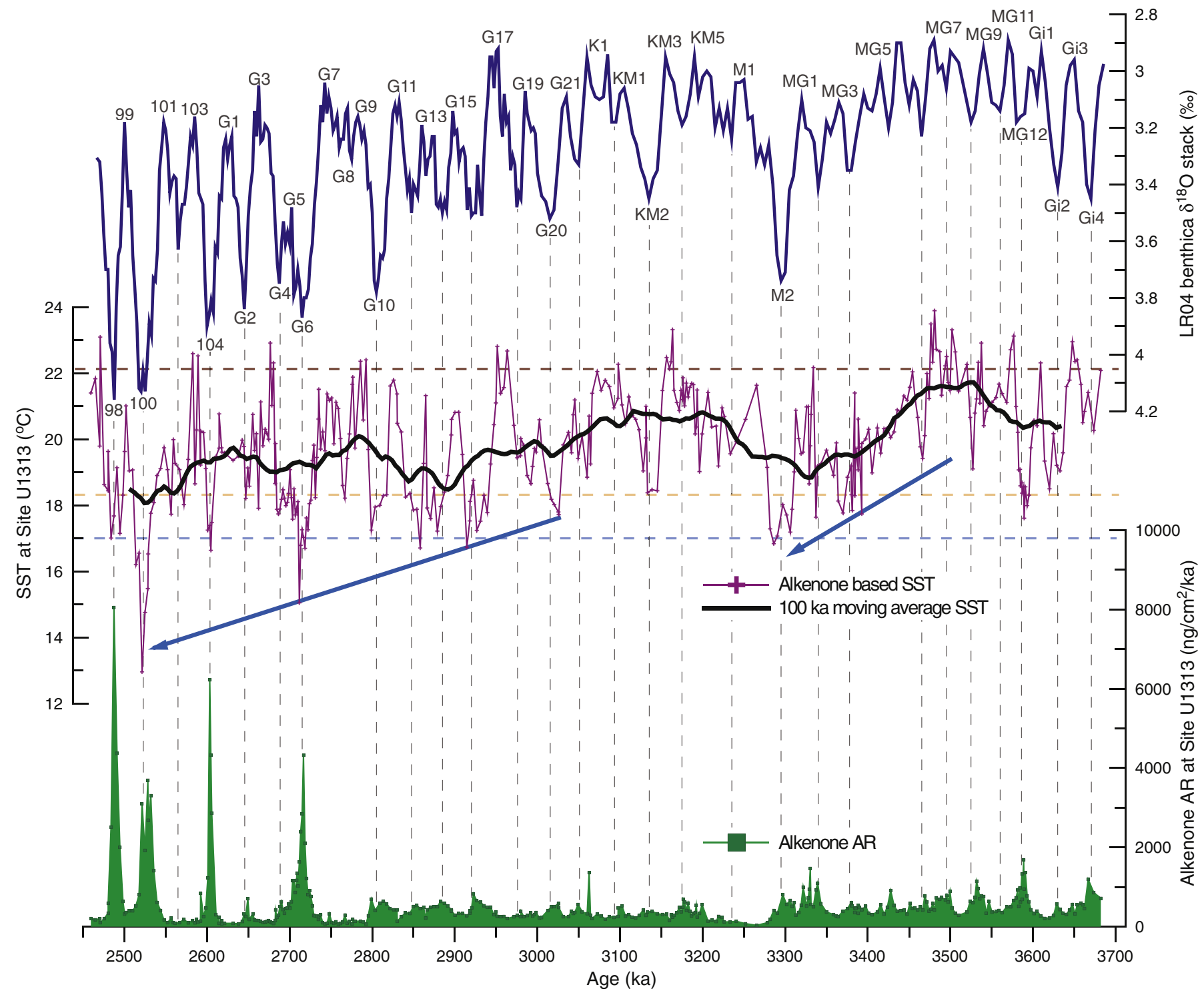

Fig. 3. Sea surface temperatures (purple) and alkenone accumulation rates (green) from Site U1313 together with the global benthic foraminiferal $\delta^{18} \mathrm{O}$ stack (blue) and marine isotope taxonomy (Lisiecki and Raymo, 2005). To obtain the 100 ka moving average of the SST record, the data was re-sampled on a 4 ka interval after which a 100 ka smoothing filter was applied. Dashed lines represent modern mean summer (JAS, in dark brown), annual (in orange), and spring (AMJ, in blue) SST at Site U1313 (Locarnini et al., 2006).

northward heat transport during this time period (De Schepper et al., 2009). In agreement with our interpretation, the palynological records at Sites 610 and 1308 suggest that the AF moved southward during MIS M2, but still remained to the north of $53^{\circ} \mathrm{N}$ (De Schepper et al., 2009). Our results show that a long-term weakening in the influence of the NAC is preceding MIS M2 and the development of a more glacial-like surface circulation in the North Atlantic. This points to a long (>100 ka) and gradual process, which might have crossed a threshold during MIS M2, as a cause for this global cooling event.

\subsection{Period between 3.29 and 2.94 Ma: warm interval}

Warm and oligotrophic conditions quickly returned at Site U1313 after MIS M2, suggesting that northward heat transport by the NAC was increased and the AF located far north of our site. This period includes the well-studied PRISM-interval between 3.29 and $2.97 \mathrm{Ma}$ (e.g., Dowsett et al., 2009). Numerous studies using sites in the North Atlantic demonstrate increased northward heat transport by an intensified NAC during this period (e.g., Cronin, 1991; Dowsett et al., 1992; Haywood and Valdes, 2004; Robinson, 2009). These reconstructions use "snap- shots" and represent warm peak averages (Robinson, 2009), making comparison with our SST record difficult.

Multi-proxy SST records, including alkenone based-SST, obtained from several sites in the North Atlantic (e.g., DSDP Sites 607 and 610) also show higher SSTs for the PRISM-interval compared to the present (Robinson et al., 2008). Although the age model and SST-calibration are slightly different, our SST estimates agree very well with the short alkenone-based SST from Site 607 for the PRISM-interval in both absolute values and trend.

The only other continuous SST record for the late Pliocene in the North Atlantic comes from ODP Site 982 (Lawrence et al., 2009). However for this interval the record differs significantly from that at Site U1313. Site 982 records a continuous cooling of surface waters that started already at 3.5 Ma, suggesting a decrease in strength of the NAC from the beginning of the late Pliocene onwards. The interval between 3.29 and $2.94 \mathrm{Ma}$ is characterized by decreasing SSTs with values occasionally as low as those during MIS M2 and G6, both major global cooling events. Especially the lack of high SST during MIS KM5 and KM3 at Site 982 , both characterized by very light benthic foraminiferal $\delta^{18} \mathrm{O}$, is different from our findings. The SST record from Site 982 might reflect a 
shift in position of the northern end of the NAC and decrease in heat transport to the northern North Atlantic since 3.5 Ma (Lawrence et al., 2009), in agreement with other studies that suggested that the built-up of continental ice sheets in the Northern Hemisphere began as early as 3.7 Ma (Meyers and Hinnov, 2010; Mudelsee and Raymo, 2005). However, a detailed revision of composite depths and magnetostratigraphy, and renewed fine-tuning of the benthic foraminiferal $\delta^{18} \mathrm{O}$ record at Site 982 led to a significant revision of the SST record of Lawrence et al. (2009) by 20 to 120 ka (Khélifi, 2010; Khélifi and Sarnthein, 2010). These authors suggested that the age of the benthic foraminiferal $\delta^{18} \mathrm{O}$ signal formally assigned to MIS KM2 $( \pm 3.135 \mathrm{Ma})$ is replaced by the age of MIS G20 $( \pm 3.015 \mathrm{Ma})$. The possible absence of the Kaena subchron in the sediment sequence of Site 982 may explain the discrepancies with our SST record.

\subsection{Period between 2.94 and $2.45 \mathrm{Ma}$ : intensification of the $\mathrm{NHG}$}

Although alkenone ARs can be influenced by various factors, we interpret the order of magnitude increase in alkenone ARs during MIS G6, 104, 100, and 98 as an increase in total surface water productivity. Because the modern North Atlantic phytoplankton community is dominated by coccolithophores, predominantly the alkenone producing E. huxleyi (Gregg and Casey, 2007), variations in the alkenone ARs reflect changes in the dominant phytoplankton group. Secondly, other studies showed that alkenone abundances in sediment cores and sediment traps track surface productivity in the North Atlantic (Incarbona et al., 2010; Rosell-Melé et al., 2000; Villanueva et al., 2001). Moreover, our alkenone ARs agree with a palynological study from Site 607 for the period between 2.85 and 2.3 Ma (Versteegh et al., 1996). That study displays increased concentrations of dinoflagellate cysts during MIS G6, 104, 100, and 98, also suggesting increased mixed layer productivity during these glacial periods.

A more than ten-fold increase in alkenone ARs is considered too large to be explained by preservation alone (Lawrence et al., 2007). Nevertheless, preservation of organic matter, including dinoflagellate cysts, can be influenced by oxygenation of the bottom waters and sediment (Versteegh and Zonneveld, 2002; Zonneveld et al., 2010). Therefore it could be argued that a decrease in bottom water ventilation during glacial periods could account for the observed increase in alkenone ARs and dinoflagellate cyst concentrations. During MIS 104, 100, and 98 benthic foraminiferal $\delta^{13} \mathrm{C}$ values were approximately $1 \%$ o lower than during interglacials (Raymo et al., 1992), reflecting increased influence of less ventilated Antarctic bottom waters at our core site. However, when a reduction in bottom water ventilation caused the increase in alkenone ARs in the North Atlantic, we would expect low benthic foraminiferal $\delta^{13} \mathrm{C}$ during all glacial periods with increased alkenone ARs. This is not the case in for example MIS G6, which is characterized by high alkenone ARs, when benthic foraminiferal $\delta^{13} \mathrm{C}$ remained high. If bottom water ventilation plays a role, then Heinrich(-like) events in the North Atlantic during the middle and late Pleistocene should also be characterized by an increase in alkenone ARs. During these events North Atlantic deepwater formation came to a halt and the deep North Atlantic basin was poorly ventilated (Vidal et al., 1997). Published alkenone records demonstrate the opposite with periods of low alkenone abundances during Heinrich(-like) events, reflecting a collapse of the phytoplankton community due to harsh surface water conditions (Stein et al., 2009; Villanueva et al., 1997). Recent high-resolution work from the Iberian Margin also shows no major influence of changes in bottom water ventilation on alkenone concentrations during the last $70 \mathrm{ka}$ (Incarbona et al., 2010).

The increased surface water productivity together with cooler SST during MIS G6, 104, 100, and 98 at Site U1313 suggests that at the end of the Pliocene the influence of the NAC weakened. The NAC then likely had a more west to east flow direction and the AF was located closer to our site (Fig. 4), comparable to the glacial conditions of the middle and late
Pleistocene (McIntyre et al., 1972; Stein et al., 2009; Villanueva et al., 2001). Such interpretation is supported by evidence from Site 607 with (1) an increase in IRD during glacials from MIS G16 onwards (Kleiven et al., 2002, updated to LR04 ages), (2) the appearance of larger sized IRD during MIS 100 and 98 (Raymo et al., 1989), and (3) occurrence of Heinrich(-like) events during MIS 100 (Becker et al., 2006). This all indicates that during peak glacial conditions icebergs could travel as far south as $41^{\circ} \mathrm{N}$ and accounts for a changed North Atlantic surface circulation, including a weakened influence of the NAC and proximity of the AF at Site U1313 during glacial periods.

\subsection{Implications of changing NAC during the intensification of the NHG}

Our study demonstrates a close correspondence between the influence of the NAC at Site U1313 and the size of Northern Hemisphere ice sheets. Periods of intense NAC at U1313 coincide with periods of small ice sheets (light benthic foraminiferal $\delta^{18} \mathrm{O}$ ) and absence of IRD in the North Atlantic (Kleiven et al., 2002). On the other hand, the influence of the AF at Site U1313 together with a weak NAC is observed for the first time during MIS G6, when the amplitude of benthic foraminiferal $\delta^{18} \mathrm{O}$ increased as continental ice volume grew larger and IRD became widespread in sediments from the North Atlantic (Kleiven et al., 2002; Ruggieri et al., 2009).

Changes in surface water characteristics in the North Atlantic led changes in ice volume (benthic foraminiferal $\delta^{18} \mathrm{O}$ ) by a few ka during the late Pliocene and early Pleistocene (De Schepper et al., 2009; Lawrence et al., 2009; Versteegh et al., 1996). This suggests that changes in the NAC and subsequent decrease in northward heat transport were a cause for the intensification of NHG rather than a result. This agrees with recent modeling results (Brierley and Fedorov, 2010; Lunt et al., 2008), which show that cooling of the higher latitudes was a necessity for the development of large continental ice sheets in the Northern Hemisphere. Although closing of the CAS might have led to a more intense northward heat transport in the early Pliocene (e.g., Haug and Tiedemann, 1998), our results show that during the late Pliocene northward heat transport diminished as continental ice volume increased. Our results support the longstanding proposal, dating back to Croll (1875), that the eastward diversion of the NAC and a positive ice-albedo feedback played a central role in the growth of Northern Hemisphere ice sheets during the Pleistocene. Moreover, the changes in polar ocean conditions such as would result from the observed NAC changes have the potential to alter ocean storage of carbon dioxide, introducing an additional dimension of climate feedback (Haug et al., 1999; Sigman et al., 2010).

\subsection{Cause for variability in NAC}

Our record of late Pliocene surface water characteristics suggests that an intense NAC transported warm tropical waters northwards, leading to a reduced meridional SST gradient during most of the late Pliocene. How such increased northward heat transport was maintained together with a weak meridional SST gradient remains controversial. Intense Atlantic deep-water circulation during the Pliocene has been proposed as a cause for increased northward heat transport (Cronin, 1991; Dowsett et al., 1992; Robinson, 2009). However, changes in surface water characteristics lead the changes in deep-water formation and ice volume by a few ka (De Schepper et al., 2009; Lawrence et al., 2009; Versteegh et al., 1996). Thus, changes in deep-water formation could only have acted as positive feedbacks for the intensity of the NAC.

Lawrence et al. (2009), similar to Versteegh et al. (1996), proposed that increased wind forcing, as modeled for the late Pliocene (Haywood et al., 2000), was responsible for maintaining the increased advection of warm surface water northwards. In their concept orbitally driven changes in solar insolation, possibly amplified by changes in sea-ice extent, altered the strength and latitudinal position 
a

\section{Warm periods (interglacials)}

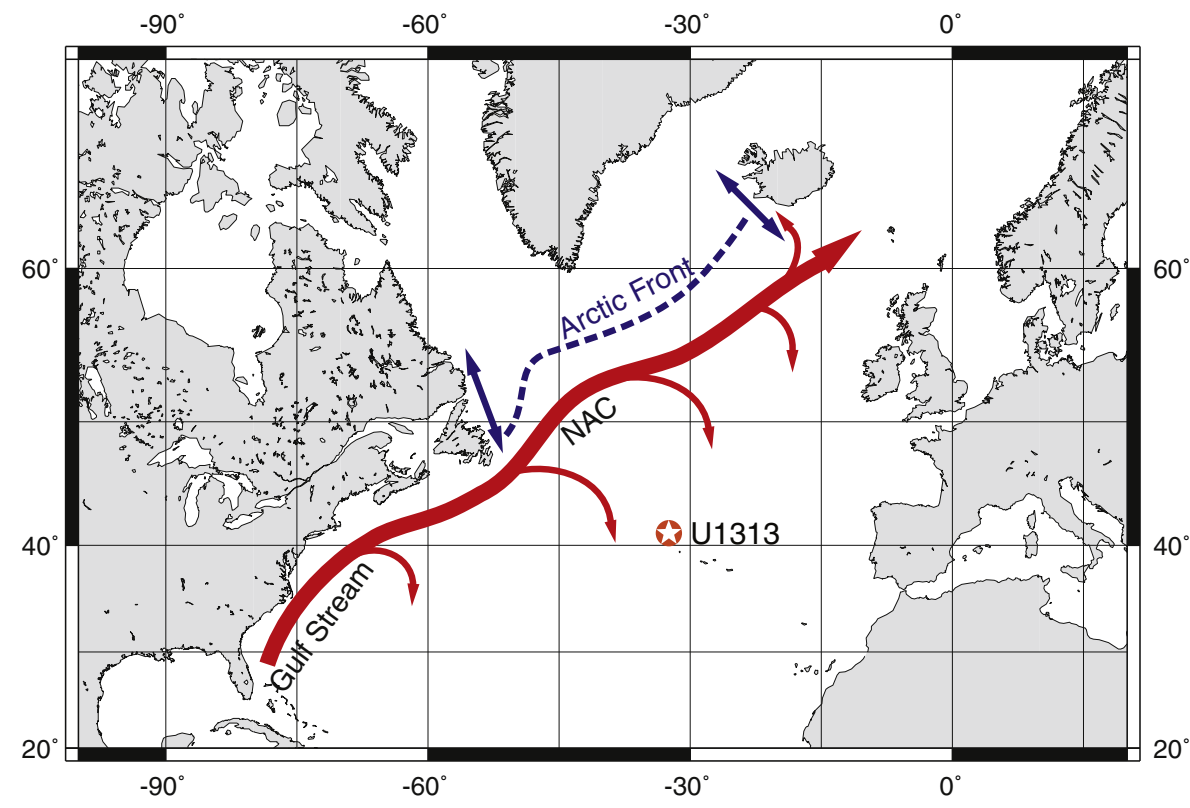

b

Severe cold periods (e.g., MIS 100)

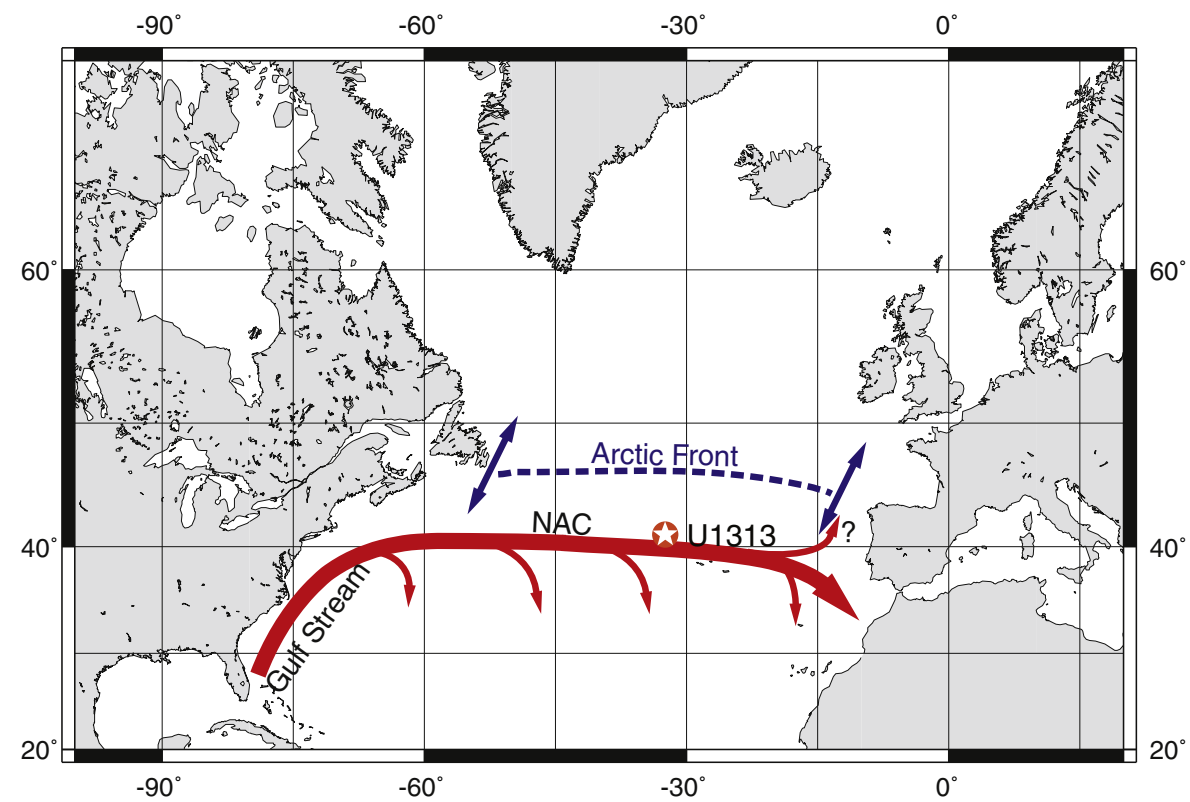

Fig. 4. a. Schematic representation of suggested position of the Gulf Stream, North Atlantic Current (NAC), and Arctic Front (AF) during warm interglacials. b. Severe glacial periods of the late Pliocene and early Pleistocene (e.g., MIS 100). Records of SSTs and surface water productivity at Site U1313 show the influence of cold and nutrient-rich surface waters during these glacials, suggesting proximity of the AF to Site U1313 and an almost purely west to east flow direction of the NAC.

of the strongest westerly winds. This would influence the position and strength of the NAC and subsequent northward heat transport. Such mechanism agrees with recent observations in which a link was found between the strength of North Atlantic pressure systems and the intensity and northward extent of the NAC on decadal (Flatau et al., 2003) and millennial time scales (Giraudeau et al., 2010).

Possibly the Northern Hemisphere ice sheets provided a positive feedback to the initial changes in wind forcing. When the ice sheets grew large enough they could start to interact with atmospheric circulation. Together with changes in deep-water formation and an increase in seaice formation as positive feedbacks, this could have led to the observed shift in the position of the NAC. Future work should focus on testing such hypothesis by palaeorecords of variations in wind strength from the mid-latitude North Atlantic, e.g. grain sizes of detrital sediments.

\section{Conclusions}

We obtained new SST and marine productivity records from the mid-latitude North Atlantic (IODP Site U1313) for the period between 3.68 and $2.45 \mathrm{Ma}$. Changes in surface water characteristics at Site U1313 provide new insights into the variations of the NAC during this critical time period. Warm SSTs and low alkenone ARs during the period between 3.65 and 2.94 Ma indicate the presence of an intense NAC in the mid-latitude North Atlantic, transporting warm tropical 
waters northwards. The final cooling of SSTs in the mid-latitude North Atlantic started around 3.1 Ma as the influence of the NAC weakened. This is later than previously suggested for the northern North Atlantic (Lawrence et al., 2009). During peak glacial conditions at the end of the Pliocene and beginning of the Pleistocene (MIS G6, 104, 100, and 98) the NAC transported less heat to the north due to a more west to east flow direction and the AF had a closer location to our study site. Surface water characteristics at our site during these glacials were similar to glacials of the late Pleistocene (Stein et al., 2009). Our results argue against an increase in northward heat transport in the North Atlantic during the intensification of NHG (Bartoli et al., 2005). The observed weakening of the NAC and subsequent decrease in northward heat transport during the late Pliocene and early Pleistocene would have led to a cooling of the higher latitudes, a condition necessary for the growth of large continental ice sheets surrounding the North Atlantic.

\section{Acknowledgments}

This research used samples and data provided by the Integrated Ocean Drilling Program. Walter Hale at the IODP depository in Bremen is acknowledged for his help during sampling. We would like to thank Robert Karandi and Walter Luttmer for technical support. Romina Wischnewski and Stefanie Kaboth are thanked for sample preparation. Diederik Liebrand helped with handling the Match 2.0 software. Gary Acton is thanked for providing the updated depth-scale for Site U1313. Gerald Langer kindly provided the E. huxleyi cultures used to obtain alkenone standards. The core of this work has been funded by the Deutsche Forschungsgemeinschaft (DFG) through B.D.A.N. S.D.S. also welcomes funding from the DFG (grant SCHE 1665/2-1). N.K. would like to acknowledge the Deutscher Akademischer Austausch Dienst (DAAD). G. Versteegh and M. Sarnthein are thanked for valueable discussions. Comments by $\mathrm{H}$. Dowsett, an anonymous reviewer, and the editor improved the manuscript and are gratefully acknowledged. Data supplement is available online at http://doi. pangaea.de/10.1594/PANGAEA.744483.

\section{Appendix A. Supplementary data}

Supplementary materials related to this article can be found online at doi:10.1016/j.epsl.2010.08.023.

\section{References}

Bartoli, G., Sarnthein, M., Weinelt, M., Erlenkeuser, H., Garbe-Schönberg, D., Lea, D.W., 2005. Final closure of Panama and the onset of northern hemisphere glaciation. Earth Planet. Sci. Lett. 237 (1-2), 33-44.

Becker, J., Lourens, L.J., Raymo, M.E., 2006. High-frequency climate linkages between the North Atlantic and the Mediterranean during marine oxygen isotope stage 100 (MIS100). Paleoceanography 21 (3), PA3002. doi:10.1029/2005pa001168.

Bendle, J., Rosell-Melé, A., Ziveri, P., 2005. Variability of unusual distributions of alkenones in the surface waters of the Nordic seas. Paleoceanography 20, PA2001 doi:2010.1029/2004PA001025.

Berger, W.H., Wefer, G., 1996. Expeditions into the past: paleoceanographic studies in the South Atlantic. In: Wefer, G., et al. (Ed.), The South Atlantic. Springer, Berlin, pp. 363-410.

Brierley, C.M., Fedorov, A.V., 2010. The relative importance of meridional and zonal SST gradients for the onset of the ice ages and Pliocene-Pleistocene climate evolution. Paleoceanography 25, PA2214 doi:2210.1029/2009PA001809.

Calvo, E., Villanueva, J., Grimalt, J.O., Boelaert, A., Labeyrie, L., 2001. New insights into the glacial latitudinal temperature gradients in the North Atlantic. Results from UK'37 sea surface temperatures and terrigenous inputs. Earth Planet. Sci. Lett. 188 (3-4), 509-519.

Conte, M.H., Sicre, M.-A., Rühlemann, C., Weber, J.C., Schulte, S., Schulz-Bull, D., Blanz, T., 2006. Global temperature calibration of the alkenone unsaturation index (UK'37) in surface waters and comparison with surface sediments. Geochem. Geophys. Geosyst. 7 (2), Q02005.

Croll, J., 1875. Climate and Time in Their Geological Relations. A theory of Secular Changes of the Earth's Climate New York.

Cronin, T.M., 1991. Pliocene shallow water paleoceanography of the North Atlantic ocean based on marine ostracodes. Quatern. Sci. Rev. 10 (2-3), 175-188.

De Schepper, S., Head, M.J., Groeneveld, J., 2009. North Atlantic Current variability through marine isotope stage M2 (circa $3.3 \mathrm{Ma}$ ) during the mid-Pliocene. Paleoceanography 24, PA4206 doi:4210.1029/2008pa001725.
Dekens, P.S., Ravelo, A.C., McCarthy, M.D., 2007. Warm upwelling regions in the Pliocene warm period. Paleoceanography 22, PA3211 doi:3210.1029/ 2006PA001394.

Dowsett, H.J., Cronin, T.M., Poore, R.Z., Thompson, R.S., Whatley, R.C., Wood, A.M., 1992. Micropaleontological evidence for increased meridional heat transport in the North Atlantic Ocean during the Pliocene. Science 258 (5085), 1133-1135.

Dowsett, H.J., Robinson, M.M., Foley, K.M., 2009. Pliocene three-dimensional global ocean temperature reconstruction. Clim. Past 5 (4), 769-783.

Driscoll, N.W., Haug, G.H., 1998. A short circuit in thermohaline circulation: a cause for Northern Hemisphere Glaciation? Science 282 (5388), 436-438.

Expedition 306 Scientists, 2006. Site U1313. In: Channell, J.E.T., et al. (Ed.), Proceedings of Integrated Ocean Drilling Program. Integrated Ocean Drilling Program Management International, Inc., College Station TX.

Flatau, M.K., Talley, L, Niiler, P.P., 2003. The North Atlantic oscillation, surface current velocities, and SST changes in the subpolar North Atlantic. J. Climate 16 (14), 2355-2369.

Gibbard, P.L., Head, M.J., Walker, M.J.C., 2009. Formal ratification of the Quaternary System/Period and the Pleistocene Series/Epoch with a base at 2.58 Ma. J. Quatern. Sci. 25 (2), 96-102.

Giraudeau, J., Grelaud, M., Solignac, S., Andrews, J.T., Moros, M., Jansen, E., 2010. Millennial-scale variability in Atlantic water advection to the Nordic Seas derived from Holocene coccolith concentration records. Quatern. Sci. Rev. 29 (9-10), $1276-1287$

Gregg, W.W., Casey, N.W., 2007. Modeling coccolithophores in the global oceans. Deep Sea Res. II 54 (5-7), 447-477.

Haug, G.H., Tiedemann, R., 1998. Effect of the formation of the Isthmus of Panama on Atlantic Ocean thermohaline circulation. Nature 393 (6686), 673-676.

Haug, G.H., Sigman, D.M., Tiedemann, R., Pedersen, T.F., Sarnthein, M., 1999. Onset of permanent stratification in the subarctic Pacific Ocean. Nature 401 (6755), 779-782.

Haug, G.H., Ganopolski, A., Sigman, D.M., Rosell-Mele, A., Swann, G.E.A., Tiedemann, R., Jaccard, S.L., Bollmann, J., et al., 2005. North Pacific seasonality and the glaciation of North America 2.7 million years ago. Nature 433 (7028), 821-825.

Haywood, A.M., Valdes, P.J., 2004. Modelling Pliocene warmth: contribution of atmosphere, oceans and cryosphere. Earth Planet. Sci. Lett. 218 (3-4), 363-377.

Haywood, A.M., Sellwood, B.W., Valdes, P.J., 2000. Regional warming: Pliocene (3 Ma) paleoclimate of Europe and the Mediterranean. Geology 28 (12), 1063-1066.

Haywood, A.M., Chandler, M.A., Valdes, P.J., Salzmann, U., Lunt, D.J., Dowsett, H.J., 2009. Comparison of mid-Pliocene climate predictions produced by the HadAM 3 and GCMAM3 General Circulation Models. Glob. Planet. Change 66 (3-4), 208-224.

Hefter, J., 2008. Analysis of alkenone unsaturation indices with fast gas chromatography/time-of-flight mass spectrometry. Anal. Chem. 80 (6), 2161-2170.

Incarbona, A., Martrat, B., Di Stefano, E., Grimalt, J.O., Pelosi, N., Patti, B., Tranchida, G., 2010. Primary productivity variability on the Atlantic Iberian Margin over the last 70,000 years: evidence from coccolithophores and fossil organic compounds. Paleoceanography 25 (2), PA2218 doi:2210.1029/2008pa001709.

Khélifi, N., 2010. Variations in Mediterranean Outflow Water and its salt discharge versus Pliocene changes in North Atlantic thermohaline circulation over the onset of Northern Hemisphere Glaciation, 3.7-2.6 Ma ago, PhD Thesis, Kiel University, 150 pp.

Khélifi, N., Sarnthein, M., 2010. Major shifts in age control at ODP S. 982 near the Pliocene onset of Northern Hemisphere Glaciation - composite depths and d180 stratigraphy revisited. Geophys. Res. Abstr. 12 EGU2010-12762-12761.

Kleiven, H.F., Jansen, E., Fronval, T., Smith, T.M., 2002. Intensification of Northern Hemisphere glaciations in the circum Atlantic region (3.5-2.4 Ma) - ice-rafted detritus evidence. Palaeogeogr. Palaeoclimatol. Palaeoecol. 184 (3-4), 213-223.

Lawrence, K.T., Herbert, T.D., Dekens, P.S., Ravelo, A.C., 2007. The application of the alkenone organic proxy to the study of Plio-Pleistocene climate. In: Williams, M., et al. (Ed.), Deep-time perspectives on climate change: marrying the signal from computer models and biological proxies. The Geological Society, London, pp. 539-565.

Lawrence, K.T., Herbert, T.D., Brown, C.M., Raymo, M.E., Haywood, A.M., 2009. Highamplitude variations in North Atlantic sea surface temperature during the early Pliocene warm period. Paleoceanography 24, PA2218 doi:2210.1029/2008pa001669.

Leduc, G., Schneider, R., Kim, J.H., Lohmann, G., 2010. Holocene and Eemian sea surface temperature trends as revealed by alkenone and $\mathrm{Mg} / \mathrm{Ca}$ paleothermometry. Quatern. Sci. Rev. 29 (7-8), 989-1004.

Lisiecki, L.E., Lisiecki, P.A., 2002. Application of dynamic programming to the correlation of paleoclimate records. Paleoceanography 17, PA1049 doi:1010.1029/2001PA000733.

Lisiecki, L.E., Raymo, M.E., 2005. A Pliocene-Pleistocene stack of 57 globally distributed benthic $\delta 180$ records. Paleoceanography 20, PA1003 doi:1010.1029/2004PA001071.

Locarnini, R.A., Mishonov, A.V., Antonov, J.I., Boyer, T.P., Garcia, H.E., 2006. Volume 1: Temperature. In: Levitus, S. (Ed.), World Ocean Atlas 2005. U.S. Government Printing Office, Washington, D.C., p. 182.

Lunt, D.J., Foster, G.L., Haywood, A.M., Stone, E.J., 2008. Late Pliocene Greenland glaciation controlled by a decline in atmospheric CO2 levels. Nature 454 (7208), 1102-1105.

Maslin, M.A., Li, X.S., Loutre, M.F., Berger, A., 1998. The contribution of orbital forcing to the progressive intensification of northern hemisphere glaciation. Quatern. Sci. Rev. 17 (4-5), 411-426.

McClymont, E.L., Rosell-MelÈ, A., Giraudeau, J., Pierre, C., Lloyd, J.M., 2005. Alkenone and coccolith records of the mid-Pleistocene in the south-east Atlantic: implications for the index and South African climate. Quatern. Sci. Rev. 24 (14-15), 1559-1572.

McIntyre, A., Ruddiman, W.F., Jantzen, R., 1972. Southward penetrations of the North Atlantic Polar Front: faunal and floral evidence of large-scale surface water mass movements over the last 225,000 years. Deep-Sea Res. 19, 61-77.

Meyers, S.R., Hinnov, L.A., 2010. Northern Hemisphere glaciation and the evolution of Plio-Pleistocene climate noise. Paleoceanography 25 (3), PA3207 doi:3210.1029/ 2009pa001834.

Mollenhauer, G., Kienast, M., Lamy, F., Meggers, H., Schneider, R.R., Hayes, J.M., Eglinton, T.I., 2005. An evaluation of $14 \mathrm{C}$ age relationships between co-occurring 
foraminifera, alkenones, and total organic carbon in continental margin sediments. Paleoceanography 20 (1), PA1016 doi:1010.1029/2004pa001103.

Mudelsee, M., Raymo, M.E., 2005. Slow dynamics of the Northern Hemisphere glaciation. Paleoceanography 20, PA4022 doi:4010.1029/2005PA001153.

Müller, P.J., Kirst, G., Ruhland, G., von Storch, I., Rosell-Melé, A., 1998. Calibration of the alkenone paleotemperature index Uk'37 based on core-tops from the eastern South Atlantic and the global ocean $\left(60^{\circ} \mathrm{N}-60^{\circ} \mathrm{S}\right)$. Geochim. Cosmochim. Acta 62 (10), 1757-1772.

Pagani, M., Liu, Z., LaRiviere, J., Ravelo, A.C., 2010. High Earth-system climate sensitivity determined from Pliocene carbon dioxide concentrations. Nat. Geosci. 3 (1), 27-30.

Pflaumann, U., Sarnthein, M., Chapman, M., de Abreu, L., Funnell, B., Huels, M., Kiefer, T. Maslin, M., et al., 2003. Glacial North Atlantic: sea-surface conditions reconstructed by GLAMAP 2000. Paleoceanography 18, 1065 doi:1010.1029/2002PA000774.

Prahl, F.G., Wakeham, S.G., 1987. Calibration of unsaturation patterns in long-chain ketone compositions for palaeotemperature assessment. Nature 330 (6146), 367-369.

Ravelo, A.C., Andreasen, D.H., Lyle, M., Olivarez Lyle, A., Wara, M.W., 2004. Regional climate shifts caused by gradual global cooling in the Pliocene epoch. Nature 429 (6989), 263-267.

Raymo, M.E., Ruddiman, W.F., Backman, J., Clement, B.M., Martinson, D.G., 1989. Late Pliocene variation in Northern Hemisphere ice sheets and North Atlantic deep water circulation. Paleoceanography 4 (4), 413-446 doi:410.1029/PA1004i1004p00413.

Raymo, M.E., Hodell, D., Jansen, E., 1992. Response of deep ocean circulation to initiation of Northern Hemisphere Glaciation (3-2 MA). Paleoceanography 7, 645-672 doi:610.1029/1092pa01609.

Robinson, M.M., 2009. New quantitative evidence of extreme warmth in the Pliocene Arctic. Stratigraphy 6 (4), 265-275.

Robinson, M.M., Dowsett, H.J., Dwyer, G.S., Lawrence, K.T., 2008. Reevaluation of mid Pliocene North Atlantic sea surface temperatures. Paleoceanography 23, PA3213 doi:3210.1029/2008pa001608.

Rosell-Melé, A., Comes, P., Müller, P.J., Ziveri, P., 2000. Alkenone fluxes and anomalous UK'37 values during $1989-1990$ in the Northeast Atlantic $\left(48^{\circ} \mathrm{N} 21^{\circ} \mathrm{W}\right)$. Mar. Chem. 71 (3-4), 251-264.

Ruddiman, W.F., Raymo, M.E., Martinson, D.G., Clement, B.M., Backman, J., 1989. Pleistocene evolution: Northern Hemisphere ice sheets and North Atlantic Ocean Paleoceanography 4, 353-412 doi:310.1029/PA1004i1004p00353.

Ruggieri, E., Herbert, T., Lawrence, K.T., Lawrence, C.E., 2009. Change point method for detecting regime shifts in paleoclimatic time series: application to d180 time series of the Plio-Pleistocene. Paleoceanography 24, PA1204 doi:1210.1029/2007pa001568.

Sarnthein, M., Bartoli, G., Prange, M., Schmittner, A., Schneider, B., Weinelt, M. Andersen, N., Garbe-Schönberg, D., 2009. Mid-Pliocene shifts in ocean overturning circulation and the onset of Quaternary-style climates. Clim. Past 5 (2), 269-283.
Seki, O., Foster, G.L., Schmidt, D.N., Mackensen, A., Kawamura, K., Pancost, R.D., 2010. Alkenone and boron-based Pliocene $\mathrm{pCO}_{2}$ records. Earth Planet. Sci. Lett. 292 (1-2), 201-211.

Shackleton, N.J., Backman, J., Zimmerman, H., Kent, D.V., Hall, M.A., Roberts, D.G., Schnitker D., Baldauf, J.G., et al., 1984. Oxygen isotope calibration of the onset of ice-rafting and history of glaciation in the North Atlantic region. Nature 307 (5952), 620-623.

Sigman, D.M., Hain, M.P., Haug, G.H., 2010. The polar ocean and glacial cycles in atmospheric CO2 concentration. Nature 466 (7302), 47-55.

Stein, R., Hefter, J., Grützner, J., Voelker, A., Naafs, B.D.A., 2009. Variability of surfacewater characteristics and Heinrich-like events in the Pleistocene mid-latitude North Atlantic Ocean: biomarker and XRD records from IODP Site U1313 (MIS 169). Paleoceanography 24, PA2203 doi:2210.1029/2008PA001639.

Swift, J., 1986. The Arctic waters. In: Hurdle, B.G. (Ed.), The Nordic Seas. Springer, New York, pp. 129-151.

Versteegh, G.J.M., Zonneveld, K.A.F., 2002. Use of selective degradation to separate preservation from productivity. Geology 30 (7), 615-618.

Versteegh, G.J.M., Brinkhuis, H., Visscher, H., Zonneveld, K.A.F., 1996. The relation between productivity and temperature in the Pliocene North Atlantic at the onset of northern hemisphere glaciation: a palynological study. Glob. Planet. Change 11 (4), 155-165.

Vidal, L., Labeyrie, L. Cortijo, E. Arnold, M., Duplessy. J.C. Michel, E. Becquè, S., van Weering, T.C.E., 1997. Evidence for changes in the North Atlantic Deep Water linked to meltwater surges during the Heinrich events. Earth Planet. Sci. Lett. 146 (1-2), 13-27.

Villanueva, J., Grimalt, J.O., Cortijo, E., Vidal, L., Labeyriez, L., 1997. A biomarker approach to the organic matter deposited in the North Atlantic during the last climatic cycle. Geochim. Cosmochim. Acta 61 (21), 4633-4646.

Villanueva, J., Calvo, E., Pelejero, C., Grimalt, J.O., Boelaert, A., Labeyrie, L., 2001. A latitudinal productivity band in the Central North Atlantic over the last 270 kyr: an alkenone perspective. Paleoceanography 16, 617-626 doi:610.1029/2000PA000543.

Villanueva, J., Flores, J.A., Grimalt, J.O., 2002. A detailed comparison of the UK'37 and coccolith records over the past 290 kyears: implications to the alkenone paleotemperature method. Org. Geochem. 33 (8), 897-905.

Volkman, J.K., Barrett, S.M., Blackburn, S.I., Sikes, E.L., 1995. Alkenones in Gephyrocapsa oceanica: implications for studies of paleoclimate. Geochim. Cosmochim. Acta 59 (3), 513-520.

Williams, R.G., Follows, M.J., 1998. Oceanography: eddies make ocean deserts bloom. Nature 394 (6690), 228-229.

Zonneveld, K.A.F., Versteegh, G.J.M., Kasten, S., Eglinton, T.I., Emeis, K.C., Huguet, C. Koch, B.P., de Lange, G.J., et al., 2010. Selective preservation of organic matter in marine environments; processes and impact on the sedimentary record. Biogeosciences 7 (2), 483-511. 